\title{
Optimization of image screen printing process on film biodegradable packaging
}

\begin{abstract}
The article presents the research results of screen printing technological parameters to produce high-quality images on oxo-biodegradable film packaging. Printing parameters that influence the ink layer resistance to abrasion and the image resolution the most significantly have been set, analysing the experimental data. A direct linear correlation between the ink layer resistance to abrasion and the size of a technological clearance as well as between the image resolution and the lineature of a screen printing plate mesh has been shown. As a result of the study, mathematical models have been designed and the optimization of screen printing parameters has been made, providing high quality imprints with image high resolution, the ink layer of which is the most resistant to abrasion.
\end{abstract}

\section{KEY WORDS}

oxo-biodegradable film, technological printing parameters, regression analysis, correlation coefficients, mathematical modelling, optimization

\author{
Viktoriya Korotka, \\ Svitlana Havenko, \\ Kseniya Bazylyuk \\ Ukrainian Academy of Printing, \\ Faculty of Publishing, Printing and \\ Information Technologies, \\ Lviv, Ukraine
}

Corresponding author: Viktoriya Korotka e-mail: viktoria.korotka@gmail.com

First recieved: 03.06.2017. Accepted: 12.07.2017.

\section{Introduction}

An integral part of our life and modern food and nonfood goods is the packaging that provides their storage, the compliance with sanitary and aesthetic requirements and standards, the ease of using and selling, it promotes the competitiveness of products and protects the rights of producers and consumers in the market. It is not a secret that it is often the well-designed and decorated packaging, which makes the buyer to buy something for the first time. Therefore, most goods packaging is primarily a harmonious unity of the material, the colour and the information for consumers. The role of each component is very important.

In terms of philosophy, packaging is a means of expression and transmission of knowledge. Introducing the goods and helping to decide quickly on its purchase are the main tasks that the packaging performs while concealing and demonstrating the goods at the same time. A good or particularly convenient packaging gives the confidence in the fact that the product itself is also of high quality. Therefore, the buyer does not spend much time and mental efforts to make a decision about its purchase. Modern communication using the packaging comes from the fact that a person, who enters the store on a subconscious level, generates an emotional response and encourages purchasing goods.

Researchers distinguish various functions of packaging metering, protecting, transporting, storing, marketing, regulatory-legal, informational, operational, environmental and so on. Environmentally friendly packaging is extremely important today. A steady trend on the modern packaging market is to reduce the environmental pollution. Increasing the consumer interest in environmental issues is a push in manufacturing the packaging that can decompose under natural conditions without causing negative effects on the environment. Of course, there are no absolutely safe for the environment types of packaging: a variety of substances, including harmful and toxic, easily get in the environment during its recycling. Therefore, the research priorities are focused on the search for such materials that can produce reliable, convenient and safe for the human and the environment packaging. Equally important is the informative and decorating function of the packaging, providing of which largely depends on the capabilities of printing 
technology, the use of modern printing techniques, printing materials (Efremov, Lemeshko \& Churkin, 2004).

Particular attention to such parameters is given when printing on non-absorbent surfaces, which include oxo-biodegradable film materials where the formation of the ink layer is associated with the intermolecular interactions at contacting surfaces level. Therefore, in case of film material printing, the rheological and printing properties of printing inks, the high adhesion to the surface, the speed of the imprint fixing are important (Humenyuk, 2010; Tkachuk, 2000). Through the optimization of technological modes of screen printing on film materials we can achieve an adequate image quality with the ink layer resistant to abrasion and high resolution (Havenko \& Hun'ko, 1996).

Therefore, the aim of the work was to optimize the parameters of screen printing technological process on oxo-biodegradable film packaging for high-quality image reproduction.

\section{Methods and materials}

As the research objects, there were used the screen printing imprints on the packaging made from these types of films (the production of Open Joint-Stock Company «Dneproplastotomat» - Ukraine):

1. the film based on high density polyethylene (HDPE), the thickness of 25 microns;

2. the film based on HDPE and oxo-biodegradable admixture $A$, the thickness of 25 microns;

3. the film based on HDPE and oxo-biodegradable admixture $B$, the thickness of 33 microns;

4. the film based on low density polyethylene (LDPE) and oxo-biodegradable admixture $\mathrm{C}$, the thickness of 95 microns;

5. the film based on LDPE, the thickness of 80 microns. In order to make a printing plate we used the screen mesh DP $140 \mathrm{~S}$ for Unirich (Singapore) with the screen mesh lineature of 100, 120, 140 threads/cm, linen weave type, thread diameter 31 microns. The universal photoemulsion MacDermid PLUS 8000 (England) was used for manufacturing of screen printing plate in an analogue way. We used direct imaging of the screen. The printing was done using a black ink, with the ink viscosity of 52, 57 and $68 \mathrm{~Pa} \mathrm{~s}$. The printing has been conducted on the semi-automatic screen printing press Toprintt S-600 DF, using a solvent-type screen printing ink of Ukrainian production by the company JSC «UkrNDISVD". Using the methods of statistical data analysis with the help of Statistica 10 package, the influence of such variable factors has been studied:

- the size of technological clear-

ance ( $\mathrm{T}$ clearance, $\mathrm{mm}$ );

- the ink viscosity (Viscosity, Pa s);
- the screen mesh lineature ( $L$ mesh, threads/cm);

- the squeegee angle (Angle, degree)

on such dependent factors:

- the ink layer resistance to abrasion (Resistance, cycles) with the thickness of 0.5 pt and 2 pt

- the image resolution (Resolution, $\mathrm{l} / \mathrm{cm}$ ).

The correlation analysis is used to set the existence and the closeness of linear correlation between the parameters. The correlation coefficient $(R)$ is a parameter that evaluates the closeness of linear correlation between the features. It can take the values from -1 to +1 . The symbol "_" means that the correlation is reverse, "+" means it is direct. The closer the coefficient is to 1, the closer is the linear correlation. When the value of the correlation coefficient is less than 0.3 , the correlation is assessed as weak, from 0.31 to 0.5 - moderate, from 0.51 to 0.7 significant, from 0.71 to 0.9 - close, 0.91 and more - very close. For practical purposes, it is recommended to use significant, close and very close correlations (Mamnych et al., 2006; Mayboroda \& Suhakova, 2012). The Correlation matrices procedure of Statistica package immediately makes it possible to check the accuracy of the calculated correlation coefficients: statistically significant at the $5 \%$ level correlation coefficients are placed in the correlation matrix on the monitor screen, and the trust level $p$ is deduced under the corresponding value of the correlation coefficient (for significant coefficients $p<0.05$ ).

The optimization of the printing process parameters has been carried out to produce high-quality images. With the help of the correlation and nonlinear regression analysis, the mathematical models of the ink layer resistance to abrasion and the image resolution for the studied samples have been designed. The reliability of the models has been determined by the coefficient of multiple correlation that characterizes the correlation between the variables in the regression equation.

\section{Results and discussion}

It has been found out that the most resistant screen printing image on the studied samples of packaging can be received with the technological clearance of $6 \mathrm{~mm}$. As seen from Table 1, the best results of resistance to abrasion have been demonstrated by the sample 4 based on LDPE and oxo-biodegradable admixture (2080 cycles - for the thread with the thickness of 0.5 pt and 3565 cycles - for the thread with the thickness 2 pt) (Korotka, Bazylyuk \& Zatserkovna, 2014). Basic statistical parameters have been calculated with the given package for the received experimental data such as the arithmetic mean, the variation, the standard deviation, the excess, coefficients of asymmetry and excess, as well as the closeness of the studied data distribution to the standard ones has 


\section{Table 1}

The ink layer resistance to abrasion for the differents type of films

\begin{tabular}{c|c|c}
\hline \multirow{2}{*}{$\begin{array}{c}\text { Numbers } \\
\text { of films }\end{array}$} & \multicolumn{2}{|c}{$\begin{array}{c}\text { The ink layer resistance to } \\
\text { abrasion (Resistance, cycles) }\end{array}$} \\
\cline { 2 - 3 } & $\begin{array}{c}\text { The thickness } \\
\text { of 0.5 pt }\end{array}$ & $\begin{array}{c}\text { The thickness } \\
\text { of 2 pt }\end{array}$ \\
\hline $\mathbf{1}$ & 305 & 450 \\
\hline $\mathbf{2}$ & 350 & 520 \\
\hline $\mathbf{3}$ & 1700 & 1910 \\
\hline $\mathbf{4}$ & 2080 & 3565 \\
\hline $\mathbf{5}$ & 1295 & 2900 \\
\hline
\end{tabular}

\section{Table 2}

Calculation of basic

statistical parameters

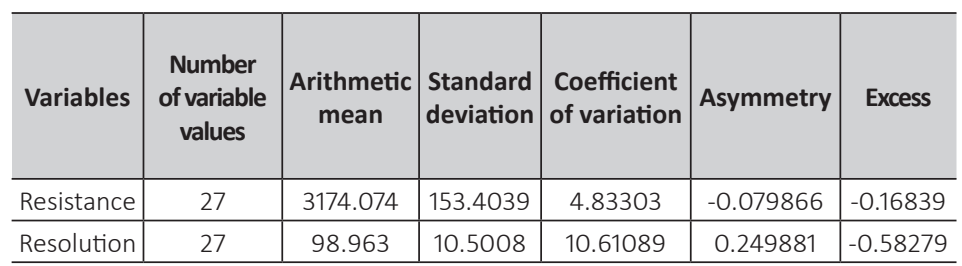

been checked. The calculation of basic statistical parameters for the resulting parameters is shown in Table 2.

The calculated parameters suggest that the distribution of these statistical series is close to standard as the symmetry and excess parameters are within the range [-1.1] and the ratio of the standard deviation to the average (the coefficient of variation) is sufficiently low (<33\%). The appropriateness of this assumption can be achieved by designing a histogram of distribution for each of the statistical series (Figure 1a and Figure1b).

In Statistica package when designing such a histogram, it is overlaid by the curve of standard distribution density besides the frequency distribution of the statistical series as a column chart. This allows us to verify the distribution of statistical series to Gaussian ones visually.

Besides visual checking, the histograms present the values of Kolmogorov-Smirnov (K-S) and Liliiefors criteria. According to the designed histograms (Figure 1a and Figure 1b), Kolmogorov-Smirnov statistics was equal to 0.15970 for the first statistical series (Figure 1a) and 0.11673 for the second statistical series. The smaller the value of this statistics is, the closer the distribution is to the standard. According to Kolmogorov-Smirn- ov and Liliiefors calculated criteria, the probability of correspondence of the series data distribution to the standard distribution is $80 \%(p>0.2)$. The calculation of statistical parameters, Kolmogorov-Smirnov and Liliiefors criteria and the designed histograms of the data distribution demonstrate the compliance of their distribution with Gaussian distribution. This allows using the procedure of classical correlation and regression analysis to the data in further processing (Mamnych et al., 2006; Mayboroda \& Suhakova, 2012).

The correlation between the studied factors has been established as a result of the conducted correlation anal$y s i s$, the received values of correlation coefficients and trust levels $\mathrm{p}$ (Table 3 ).

Results of the correlation study indicate a linear, directly proportional correlation between the values of resolution and the lineature of the screen printing plate mesh. The correlation coefficient equals to 0.6162 . This correlation indicates that the growth of the lineature of the screen printing plate mesh leads to an increase in the resolution of the printed image. There is a nonlinear correlation among other variables (Rudenko, 2012; Turchyn, 2006).

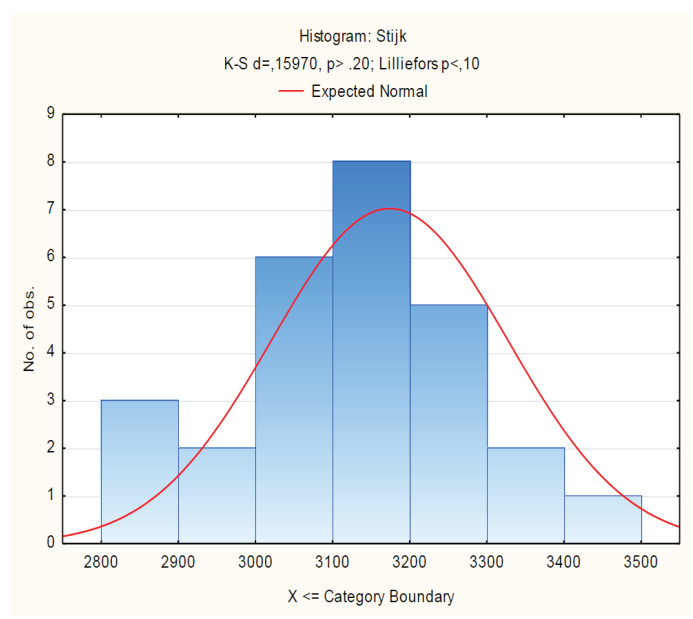

a)

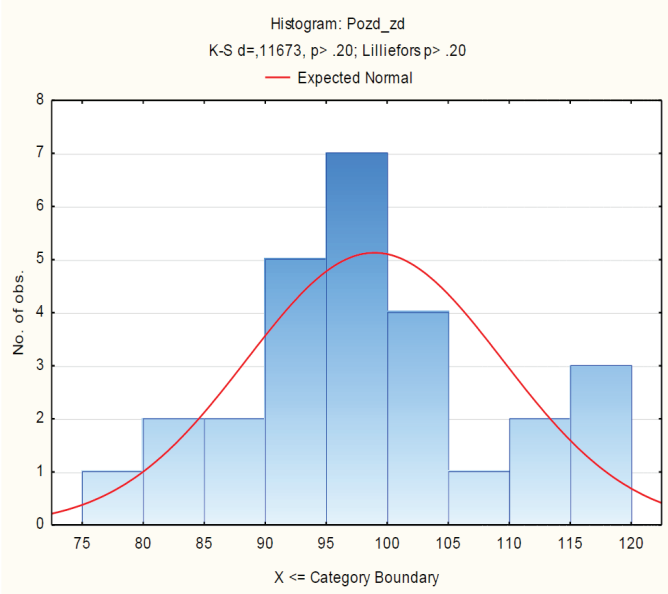

b)

» Figure 1: Histograms of data distribution of the ink layer resistance to abrasion (a) and the image resolution (b) 
Table 3

Correlation analysis of experimental data

\begin{tabular}{c|c|c|c|c|c|c|c|c}
\hline & $\begin{array}{c}\text { Arithmetic } \\
\text { mean }\end{array}$ & $\begin{array}{c}\text { Standard } \\
\text { deviation }\end{array}$ & Viscosity & T clea-rance & L mesh & Angle & Resistance & Resolution \\
\hline Viscosity & 59.000 & 6.8106 & 1.000000 & -0.00000 & 0.000000 & -0.01398 & 0.20247 & 0.2968 \\
\hline T clearance & 4.000 & 1.6641 & -0.000000 & 1.000000 & 0.000000 & -0.28614 & 0.36159 & -0.2465 \\
\hline L mesh & 120.000 & 16.641 & 0.000000 & 0.000000 & 1.000000 & 0.057229 & 0.21093 & 0.6162 \\
\hline Angle & 75.370 & 8.0773 & -0.01398 & -0.28614 & 0.057229 & 1.000000 & 0.07012 & 0.0953 \\
\hline Resistance & 3174.07 & 153.40 & 0.20247 & 0.361595 & 0.21093 & 0.07012 & 1.00000 & 0.3455 \\
\hline Resolution & 98.963 & 10.500 & 0.2968 & -0.2465 & 0.6162 & 0.0953 & 0.3455 & 1.0000 \\
\hline
\end{tabular}

Initially, the mathematical models of the ink layer resistance to abrasion and the image resolution have been designed using the linear Multiple Regression module of Statistica statistical package. The results of multiple regression analysis as to the ink layer resistance to abrasion are shown in Table 4, where:

$\mathrm{R}$ - is the coefficient of multiple correlation that characterizes the correlation extent of a resultant parameter to all the independent variables (the impact is stronger, when it is closer to 1$), R \in(0.1)$;

R2 - is the coefficient of multiple determination that determines the amount of influence of independent factors taken into account by regression (Borovikov \& Borovikov, 1998).

The received results show that the size of the technological clearance has the greatest impact on the ink layer resistance to abrasion (the standardized value of the correlation coefficient beta $=0.413$ ), the angle inclination has the lowest impact (beta $=0.18$ ).

The results of multiple regression analysis for the image resolution has shown that the lineature of the screen mesh has the greatest impact on the resolution (beta = 0.617 ) and the squeegee angle has the lowest impact (beta $=-0.0068)$. The linear model designed for the image resolution is adequate $(p<0.00174)$ as a major influence on the resolution is done by the lineature of the printing plate mesh, the dependence on which is linear that is proved by the values of coefficients of partial correlation (Table 5).

Thus, the mathematical models of the ink layer resistance to abrasion and the image resolution are nonlinear. The visualization of experimental data has been performed by designing the appropriate three-dimensional surface to determine the nature of the nonlinear dependence of

\section{Table 4}

Results of multiple regression analysis for the data of the ink layer resistance to abrasion

\begin{tabular}{c|c|c|c|c|c|c}
\hline & beta & $\begin{array}{c}\text { Standard } \\
\text { deviation beta }\end{array}$ & $\begin{array}{c}\text { b-value of } \\
\text { the coefficient } \\
\text { of regression } \\
\text { equation }\end{array}$ & $\begin{array}{c}\text { Standard } \\
\text { deviation b }\end{array}$ & $\begin{array}{c}\text { Value of } \\
\text { Student's t test }\end{array}$ & $\begin{array}{c}\text { Trust level for } \\
\text { the regression } \\
\text { coefficients }\end{array}$ \\
\hline Free member of regression & & & $\mathbf{2 2 7 0 . 1 9 5}$ & $\mathbf{4 3 7 . 4 9 2 4}$ & $\mathbf{5 . 1 8 9 1 0 7}$ & $\mathbf{0 . 0 0 0 0 3 3}$ \\
\hline Viscosity & 0.204985 & 0.185177 & 4.617 & 4.1710 & 1.106969 & 0.280265 \\
\hline T clearance & $\mathbf{0 . 4 1 3 0 1 2}$ & $\mathbf{0 . 1 9 3 2 6 7}$ & $\mathbf{3 8 . 0 7 3}$ & $\mathbf{1 7 . 8 1 6 2}$ & $\mathbf{2 . 1 3 7 0 0 4}$ & $\mathbf{0 . 0 4 3 9 6 5}$ \\
\hline L mesh & 0.200647 & 0.185488 & 1.850 & 1.7099 & 1.081721 & 0.291092 \\
\hline Angle & 0.179692 & 0.193603 & 3.413 & 3.6769 & 0.928147 & 0.363403 \\
\hline
\end{tabular}

Table 5

Partial correlation for the data of the image resolution

\begin{tabular}{c|c|c|c|c|c|c|c}
\hline & beta & $\begin{array}{c}\text { Partial } \\
\text { correlation }\end{array}$ & $\begin{array}{c}\text { Semi-partial } \\
\text { correlation }\end{array}$ & $\begin{array}{c}\text { Standard } \\
\text { deviation }\end{array}$ & R- square & $\begin{array}{c}\text { Value of } \\
\text { Student's t test }\end{array}$ & $\begin{array}{c}\text { Trust level for } \\
\text { the regression } \\
\text { coefficients }\end{array}$ \\
\hline Viscosity & 0.296766 & 0.396774 & 0.296734 & 0.999786 & 0.000214 & 2.02745 & 0.054900 \\
\hline T clearance & -0.248472 & -0.327624 & -0.238046 & 0.917837 & 0.082163 & -1.62646 & 0.118091 \\
\hline L mesh & $\mathbf{0 . 6 1 6 6 7 6}$ & $\mathbf{0 . 6 6 7 6 1 1}$ & $\mathbf{0 . 6 1 5 5 7 4}$ & $\mathbf{0 . 9 9 6 4 3 2}$ & $\mathbf{0 . 0 0 3 5 6 8}$ & $\mathbf{4 . 2 0 5 9 5}$ & $\mathbf{0 . 0 0 0 3 6 5}$ \\
\hline Angle & -0.006846 & -0.009537 & -0.006547 & 0.914652 & 0.085348 & -0.04473 & 0.964722 \\
\hline
\end{tabular}




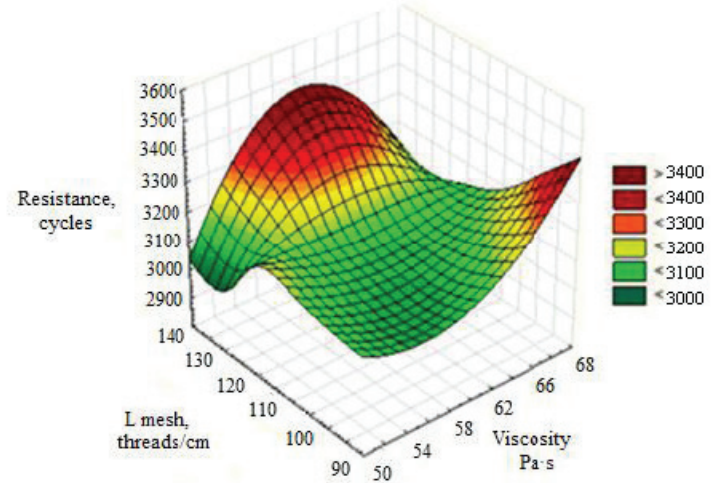

» Figure 2: A three-dimensional model of changes dependence of the ink layer resistance to abrasion on the values of the ink viscosity and the lineature of the screen mesh

the values of the ink layer resistance to abrasion on the values of the ink viscosity and the lineature of the screen printing plate mesh. The shape of the surface suggests that the studied dependence is polynomial (Figure 2).

The high coefficient of multiple correlation $(R=0.82301)$ shows the adequacy of the model as well as the values of trust levels ( $p$-level <0.05) confirming the reliability of coefficients of the received regression dependence.

To summarize the above calculations, the following symbols have been introduced:

$\mathrm{S}$ - is the ink layer resistance to abrasion; $\mathrm{w}$ - is the viscosity; $z$ - is the technological clearance; I - is the lineature of the printing plate mesh; $\alpha$ - is the squeegee angle and a nonlinear mathematical model for calculating the ink layer resistance to abrasion has been received:

$S=a+b \times w+b 2 \times w 2+c \times z+d \times 1+d 2 \times 12+k \times a+k 2 \times a 2$

Substituting the experimental research data into the expression (1), we get the model:

$\mathrm{S}=-4176.74+0.008578 \times w+0.040438 \times w 2+69.38775 \times$ $z-28.5724 \times 1+0.124824 \times 12+224.2646 \times \alpha-1.45813 \times \alpha 2$

The three-dimensional polynomial model of changes dependence of the image resolution on the values of the ink viscosity and the squeegee angle is shown in Figure 3.

The high coefficient of multiple correlation ( $R=0.82751$ ) shows the adequacy of the model as well as the value of trust levels ( $p$-level <0.05) confirming the reliability of coefficients of the received regression dependence.

Using the above-formalized parameters and denoting the image resolution as $D$, we get the mathematical model for calculating the image resolution:

$D=a+b \times w+b 2 \times w 2+c \times z+d \times 1+k \times a+k 2 \times a 2$

(2) $2 \leq z \leq 6$
$52 \leq w \leq 68$

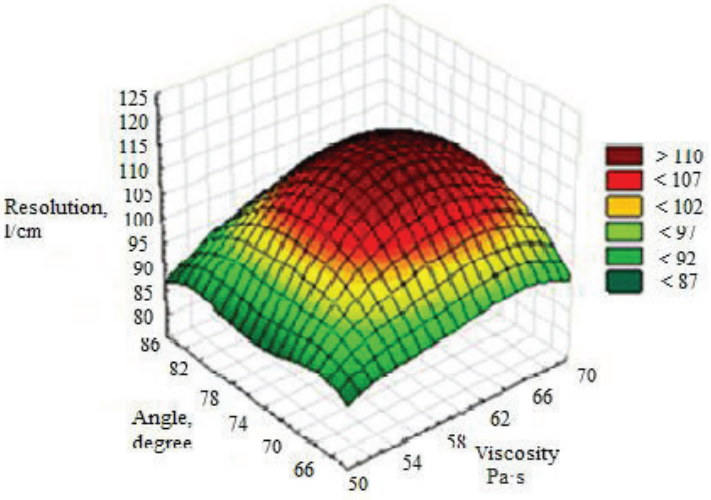

» Figure 3: The three-dimensional polynomial model of changes dependence of the image resolution on the values of the ink viscosity and the squeegee angle

Substituting the data of experimental studies into the expression (2), we get the model:

$D=-792.964+12.67962 \times w-0.101034 \times w 2+0.141176 \times$ $z+0.363922 \times 1+12.19765 \times \alpha-0.080706 \times \alpha 2$.

The designed mathematical models were used to find the optimal printing parameters. The optimization task was to find the values of printing parameters (the squeegee angle, the ink viscosity, the lineature of the screen printing plate mesh and the size of the technological clearance) with which we receive the image that is the most resistant to abrasion with maximum resolution. The solution of the problem was carried out using the mathematical package of Mathcad.

The mathematical formulation of the optimization task in the case of the study of the ink layer resistance to abrasion is as follows. Taking into account (1), we write: $S=f(w . z . \mid . \alpha)$

We must know the maximum value of the ink layer resistance to abrasion under certain restrictions on the parameters, i.e.: $f$ (w. z. I. $\alpha) \rightarrow$ max.

if

$52 \leq w \leq 68$

$2 \leq \mathrm{z} \leq 6$

$100 \leq 1 \leq 140$;

$65 \leq \alpha \leq 85$.

Similarly, we formulate the optimization task in the case of the study of the image resolution using the mathematical model received above. Taking into account (2), we write: $D=f($ w. z. I. $\alpha)$

We must know the maximum value of the image resolution under certain restrictions on the parameters.

i.e. $f($ w. z. I. $\alpha) \rightarrow$ max.

if 
$100 \leq 1 \leq 140$

$65 \leq \alpha \leq 85$.

To perform the optimization tasks of the determination of the maximum value of the ink layer resistance to abrasion, we have set the following printing parameters: the ink viscosity of $68 \mathrm{~Pa}$ s, the size of the technological clearance of $6 \mathrm{~mm}$, the lineature of the screen printing plate mesh of 140 threads $/ \mathrm{cm}$, the squeegee angle of 75 degrees.

Thus, $\max S(68 ; 6 ; 140 ; 75)=3.497 \times 103 \sim 3500$ cycles.

To receive the maximum value of the image resolution $(\max D=(63 ; 6 ; 140 ; 75)=117.529 \sim 120 \mathrm{l} / \mathrm{cm})$, we have supposed that the ink viscosity is $63 \mathrm{~Pa} \mathrm{~s}$, the size of the technological clearance is $6 \mathrm{~mm}$, the lineature of the screen printing plate mesh is 140 threads $/ \mathrm{cm}$, the squeegee angle is 75 degrees (Korotka, Bazylyuk \& Zatserkovna, 2015).

\section{Conclusions}

The mathematical models has been designed as a result of solving the optimization tasks, taking into account the screen printing parameters to produce high-quality images on oxo-biodegradable film packaging. The adequacy of the obtained three-dimensional models of polynomial dependence of the change the image resolution on the ink viscosity and the squeegee angle, as well as the ink layer resistance to abrasion on the screen mesh lineature and the ink viscosity is confirmed by the high coefficient of multiple correlation $(R=0.82751)$ and the value of trust levels ( $p$-level <0.05). It has been found out that the high quality and maximally resistant to abrasion images (up to 3500 cycles) with high resolution (120 I/ $\mathrm{cm}$ ) is achieved with screen printing on films based on LDPE and oxo-biodegradable admixture using the ink viscosity of $65 \mathrm{~Pa}$ s; the lineature of screen printing plate mesh of 140 threads/cm; the technological clearance size of $6 \mathrm{~mm}$ and the squeegee angle of 75 degrees.

\section{References}

Borovikov, I. P., Borovikov, V. P. (1997) Statistica-Statistical Analysis and Data Processing in Windows. [Statistica - Статистический анализ и обработка данных в среде Windows]. Moscow, Filin.

Efremov, N. F., Lemeshko, T. V., Churkin, A. V. (2004) Engineering and Design of Tare and Packaging. [Конструирование и дизайн тары и упаковки]. Moscow, Moscow State University of Printing.

Havenko, S. F., Hun'ko, S. M. (1996) Principles of Modeling Technical Systems in Printing. [Принцип моделювання технічних систем у поліграфії]. Lviv, Manuskrypt.
Humenyuk, O. V. (2010) Factors of Influence on Quality Indicators of the Screen Printing Prints. [Фактори впливу на якісні показники відбитка трафаретного друку]. Технологія і техніка друкарства. 2 (28), 23-27. Available from: http:// irbis-nbuv.gov.ua/cgi-bin/irbis_nbuv/cgiirbis_64. exe?C21COM=2\&I21DBN=UJRN\&P21DBN=UJRN\&IMAGE_FILE_DOWNLOAD=1\&Image_file_name=PDF/ Titd_2010_2_7.pdf [Accessed 20th May 2017].

Korotka, V. O., Bazylyuk, K. F., Zatserkovna, R. S. (2014) Use of Methods of Mathematical Statistics to Assess the Quality of Screen Printing Prints on the Oxо-Biodegradable Films. [Використання методів математичної статистики для оцінки якості відбитків трафаретного друку на оксо-біодеградуючих плівках]. Наукові Записки / Scientific Papers. 3 (48), 86-90. Available from: http://nz.uad.Iviv.ua/static/ media/3-48/18.pdf [Accessed 24th May 2017].

Mamnych, T., Olenko, A., Osypchuk, M., Shportyuk, V. (2006) Statistical Analysis with Statistica. [Cтатистичний аналіз даних з пакетом Statistica]. Drohobych, Renaissance.

Mayboroda, R. Ye., Suhakova, O. V. (2012) Statistical Analysis Using Statistica. [Cmamистичний аналіз даних за допомогою пакета Statistica-6]. Kyiv, Publishing Laboratory of the Radiophysics Faculty of the Taras Shevchenko National University of Kyiv.

Rudenko, V. M. (2012) Mathematical Statistics. [Maтематична статистика]. Kyiv, Center of Educational Literature.

Tkachuk, M. P. (2000) Screen Printing. [Трафраретний друк]. Kyiv, HaGar.

Turchyn, V. M. (2006) Probability Theory and Mathematical Statistics. Basic Concepts, Examples, Tasks. [Теорія ймовірностей і математична статистика. Основні поняття, приклади, задачі: підручник для студентів вищих навчальних закладів]. Dnipropetrovsk National University.

Vakula, V. L., Prityikin, L. M. (1984) Physical Chemistry of Polymer Adhesion. [Физическая химия адгезии полимеров]. Moscow, Chemistry.

Korotka, V. O., Bazylyuk, K. F., Zatserkovna, R. S. (2015) The Screen Printing Technology on the Oxo-Biodegradable Film Materials Packaging. [Оптимізація технологічних параметрів трафаретного друку на оксо-біорозкладальних плівках]. Наукові Записки / Scientific Papers. Available from: http://nz.uad.lviv.ua/ static/media/1-50/7.pdf [Accessed 23th May 2017]. 


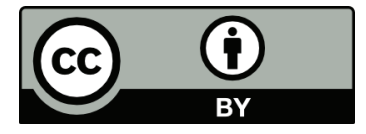

(C) 2017 Authors. Published by the University of Novi Sad, Faculty of Technical Sciences, Department of Graphic Engineering and Design. This article is an open access article distributed under the terms and conditions of the Creative Commons Attribution license 3.0 Serbia (http://creativecommons.org/licenses/by/3.0/rs/). 